\title{
Penerapan Model Discovery Learning untuk Meningkatkan Keaktifan dan Hasil Belajar Tematik
}

\author{
Iin Puji Rahayu ${ }^{1 *}$, Agustina Tyas Asri Hardini² \\ 1,2 Jurusan Pendidikan Guru Sekolah Dasar Universitas Kristen Satya Wacana Salatiga, Indonesia
}

\begin{tabular}{l} 
A R T I C L E I N F O \\
\hline Article history: \\
Received 20 May 2019 \\
Received in revised form \\
10 June 2019 \\
Accepted 30 July 2019 \\
Available online 28 \\
August 2019 \\
\hline
\end{tabular}

Kata Kunci:

discovery learning, keaktifan, hasil belajar, pembelajaran tematik.

Keywords:

discovery learning, student learning activity, learning outcomes, thematic learning.

\begin{abstract}
A B S T R A K
Penelitian ini bertujuan untuk mengetahui peningkatan keaktifan dan hasil belajar setelah menerapkan model Discovery Learning pada pembelajaran tematik di kelas VA SD Negeri Cebongan 02 Salatiga semester II tahun pelajaran 2018/ 2019. Subjek penelitian ini adalah siswa kelas VA sebanyak 22 siswa yang terdiri dari 10 siswa laki-laki dan 12 siswa perempuan. Jenis penelitian yang digunakan yaitu penelitian tindakan kelas yang dilaksanakan dalam dua siklus. Setiap siklus dilaksanakan dengan empat tahap yaitu perencanaan, pelaksanaan, observasi, dan refleksi. Data yang dikumpulkan dalam penelitian ini adalah data tentang keaktifan siswa dan hasil belajar siswa dengan metode observasi dan tes, kemudian data yang didapatkan dianalisis secara deskriptif. Pada pra siklus presentase hasil belajar siswa yang mengalami ketuntasan hanya sebesar 27,27\%, kemudian meningkat menjadi $59,09 \%$ pada siklus I dan meningkat kembali menjadi $86,36 \%$ pada siklus II. Sedangkan untuk keaktifan dari pra siklus presentase siswa yang termasuk dalam kriteria aktif sebesar $22,73 \%$, kemudian meningkat menjadi $54,55 \%$ di siklus I dan meningkat kembali menjadi 81,82 di siklus II. Peningkatan tersebut terjadi karena guru telah menerapkan model pembelajaran sesuai sintaknya dan dapat
\end{abstract} memancing siswa untuk terlibat aktif dalam pembelajaran sehingga siswa dapat memahami materi secara leluasa. Berdasarkan hal tersebut dapat disimpulkan bahwa penerapan model discovery learning dapat meningkatkan keaktifan dan hasil belajar siswa pada pembelajaran tematik.

\section{A B S T R A C T}

This study aims to determine the increase in activeness and learning outcomes after applying the Discovery Learning model in thematic learning in the fifth grade students of SD N Cebongan 02 Salatiga in the second semester of the 2018/2019 academic year. The subject of this study were 22 fifth grade students consisting of 10 male students and 12 female students. The type of research used is classroom action research conducted in two cycles. Each cycle is carried out with four stages, namely planning, implementation, observation, and reflection. The data collected in this study is data about the learns activy and learning outcomes of students with observation and test method, then the data obtained is then analyzed descriptively. In the pre cycle the percentage of learning outcomes of students who experienced completeness was only $27.27 \%$, then increased to $59.09 \%$ in the first cycle and increased again to $86.36 \%$ in the second cycle. Whereas for the activity of the pre cycle the percentage of students included in the active learning criteria was $22.73 \%$, then increased to $54.55 \%$ in the first cycle and increased again to 81.82 in the second cycle. The increase occurs because the teacher has applied the learning model according to its syntax and can provoke students to be actively involved in learning so students can understand the material freely. Based on this, it can be concluded that the application of the discovery learning model can increase student learning activity and learning outcomes in thematic learning. 


\section{Pendahuluan}

Perkembangan suatu bangsa salah satunya dipengaruhi oleh bagaimana pendidikan pada bangsa tersebut, jika pendidikannya baik maka dapat dikatakan pula perkembangan bangsa itu baik. Pendidikan menjadi faktor penting untuk menciptakan sumber daya manusia yang berkualitas yang dapat mengembangkan suatu bangsa. Salah satu cara meningkatkan pendidikan di Indonesia yaitu dengan menerapkan pembelajaran berbasis Kurikulum 2013 di sekolah. Pada Pembelajaran Kurikulum 2013 dilaksanakan dengan pembelajaran tematik. Rusman (2012:254) menyatakan bahwa pembelajaran tematik ialah salah satu model pembelajaran terpadu (integrated instruction) atau suatu sistem pembelajaran yang memungkinkan siswa baik secara individual maupun kelompok aktif menggali dan menemukan konsep serta prinsip-prinsip keilmuan secara holistik, bermakna dan otentik. Pembelajaran tematik merupakan pembelajaran yang memungkinkan siswa untuk aktif menemukan konsep materi sendiri.

Dalam pembelajaran tematik, siswa diharuskan untuk terlibat aktif dalam proses pembelajaran, sehingga siswa dapat memperoleh pengalaman langsung yang lebih bermakna dan menemukan konsep materi sendiri berdasarkan pengalamannya. Sesuai dengan prinsip yang perlu diterapkan dalam pembelajaran tematik pada kurikulum 2013, yaitu memotivasi siswa agar aktif mencari tahu, bukan diberi tahu (Aini \& Relmasira, 2018:2). Maka dari itu keaktifan siswa dalam proses belajar pada pembelajaran tematik menjadi salah satu aspek yang perlu dikembangkan pada diri siswa, karena keaktifan ini akan menuntut siswa untuk memiliki keberanian dan percaya diri sehingga memiliki kemampuan untuk terbiasa mencari tahu atau melakukan sesuatu sendiri.

Berdasarkan hasil observasi awal pada pra siklus yang dilakukan peneliti di kelas VA SDN Cebongan 02 Salatiga pada pembelajaran tematik diperoleh bahwa keaktifan siswa dalam pembelajaran ternyata masih rendah sehingga hasil belajar siswa juga rendah, hanya terdapat 6 siswa yang nilainya mencapai KKM, khususnya muatan IPA. Permasalahan yang terjadi dalam proses pembelajaran di kelas VA SD Negeri Cebongan 02 Salatiga yaitu bahwa siswa pasif ketika proses pembelajaran, terlihat dari sedikitnya siswa yang merespon pertanyaan guru, siswa juga enggan untuk bertanya, siswa selalu merasa cukup dengan materi yang diberikan guru, ketika berdiskusi siswa juga enggan untuk berpendapat, dan siswa mudah lupa dengan materi yang disampaikan guru karena siswa hanya menerima suatu konsep materi yang disampaikan dari guru tanpa aktif menemukan sendiri suatu konsep, sehingga pada akhirnya hasil belajar siswa juga rendah. Rendahnya keaktifan dan hasil belajar siswa juga diteliti oleh Rita Y (2017) dan Istikomah, dkk (2018) yang menunjukkan rendahnya keaktifan dan hasil belajar dikarenakan pembelajaran yang berpusat pada guru dan belum memberikan pengalaman yang bermakna yang sehingga mempengaruhi hasil belajar siswa.

Berdasarkan permasalahan yang diuraikan di atas, maka dalam pembelajaran tematik perlu menerapkan model pembelajaran yang bersifat aktif yang dapat meningkatkan keaktifan belajar siswa, sehingga dengan meningkatnya keaktifan tersebut dapat meningkatkan hasil belajar siswa. Salah satu model yang dapat meningkatkan keaktifan dan juga hasil belajar siswa yaitu model Discovery Learning, model ini akan menuntut siswa terlibat aktif dalam proses pembelajaran dan menemukan sendiri suatu konsep pembelajaran, karena pada proses pembelajaran materi tidak disampaikan secara utuh (Maharani \& Hardini, 2017:552). Model Discovery Learning mengajarkan anak untuk aktif menemukan sendiri konsep materi atau mencari informasi sendiri tanpa diberi tahu oleh pengajar terlebih dahulu mengenai materinya sehingga apa yang telah ditemukan sendiri oleh anak akan lebih tahan lama dalam ingatan.

Penelitian ini akan membahas bagaimana penerapan model pembelajaran Discovery Learning dalam meningkatkan keaktifan dan hasil belajar siswa, apakah penerapan model Discovery Learning dapat meningkatkan keaktifan dan hasil belajar siswa kelas VA SD Negeri Cebongan 02 Salatiga. Sehingga penelitian ini bertujuan untuk mengetahui peningkatan keaktifan dan hasil belajar siswa kelas VA SD Negeri Cebongan 02 Salatiga setelah menerapkan model pembelajaran Discovery Learning.

Hosnan (2014:282) menyatakan bahwa Discovery Learning adalah suatu model untuk mengembangkan cara belajar siswa aktif dengan menemukan sendiri, menyelidiki sendiri, maka hasil yang diperoleh akan setia, tahan lama dalam ingatan dan tidak akan mudah untuk dilupakan siswa, melalui model penemuan siswa juga bisa belajar berfikir analisis dan mencoba memecahkan sendiri masalah yang dihadapi. Sesuai dengan makna discovery learning dalam proses pembelajaran bahwa guru hanya sebagai fasilitator untuk memberi rangsangan agar siswa merasa tertantang untuk ikut terlibat dalam proses pembelajaran dan siswa adalah sebjeknya (Putrayasa, dkk, 2014:9). Pada pembelajaran discovery learning melibatkan siswa dalam proses kegiatan mental melalui tukar pendapat, dengan diskusi, membaca informasi dari berbagai sumber sendiri, ataupun melakukan pengamatan dan percobaan sendiri. Discovery Learning mengarahkan siswa menemukan konsep melalui berbagai informasi atau data yang diperoleh melalui pengamatan atau percobaan (Kristin, dkk, 2018:71). Sedangkan kelebihan dari model discovery learning diantaranya adalah:1) Meningkatkan kemampuan 
siswa untuk memecahkan masalah. 2) Membantu siswa memperkuat konsep dirinya, karena memperoleh kepercayaan bekerja sama dengan yang lain. 3) Mendorong keterlibatan keaktifan siswa. 4) Mendorong siswa berpikir intuisi dan merumuskan hipotesis sendiri. 5) Melatih siswa belajar mandiri. 6) Siswa aktif dalam kegiatan belajar mengajar, karena ia berpikir dan menggunakan kemampuan untuk menemukan hasil akhir (Hosnan, 2014:287-288). Kemudian Kurniasih \& Sani (2014:68-71) telah menyebutkan langkah-langkah dalam menerapan model discovery learning, yaitu: 1) Stimulation (stimulasi/pemberian rangsang). 2) Problem statemen (pernyataan/identifikasi masalah). 3) Data collection (pengumpulan data). 4) Data processing (pengolahan data). 5) Verification (pembuktian). 6) Generalization (menarik kesimpulan).

Sedangkan keaktifan adalah kegiatan atau aktivitas atau segala sesuatu yang dilakukan atau kegiatan-kegiatan yang terjadi baik fisik maupun non fisik Mulyono (Kurniati, 2009:12). Keaktifan belajar disini dapat dikatakan segala kegiatan yang melibatkan pikiran dan tindakan yang dialami siswa ketika belajar. Menurut Budimansyah (2009:70) keaktifan belajar merupakan proses pembelajaran di mana guru harus menciptakan suasana sedemikian rupa sehingga siswa dapat aktif mengajukan pertanyaan, dapat mengemukakan gagasan, dan mencari data atau informasi yang mereka perlukan untuk memecahkan masalah. Berdasarkan hal itu dapat diketahui bahwa siswa yang aktif dalam belajar ialah siswa yang mampu bertanya pada guru maupun sesama siswa, mampu bekerja sama kelompok dengan siswa lain, mampu menyampaikan hasil diskusi kelompok, dan mampu berpendapat atau menanggapi pendapat orang lain. Keaktifan belajar siswa berguna untuk menumbuhkan kemampuan belajar aktif pada diri siswa serta menggali potensi siswa dan guru untuk sama-sama berkembang dan berbagi pengetahuan, keterampiran, dan pengalaman (Aningsih \& Irnawati, 2018:53).

Hasil belajar merupakan sesuatu yang berupa akibat yang diperoleh dari kegiatan belajar. Sesuai dengan pendapat Septiyani \& Rosnita (2018:4) bahwa hasil belajar ialah kemampuan yang dimiliki siswa setelah melewati proses belajar. Hasil belajar siswa dipengaruhi beberapa faktor pendukung, yaitu: 1) faktor internal, yang meliputi faktor fisiologis dan psikologis; 2) faktor eksternal, yang meliputi faktor lingkungan sosial dan nonlingkungan sosial, peran siswa, peran guru dan model pembelajaran yang digunakan (Widayanti \& Slameto, 2016:187).

\section{Metode}

Subjek dalam penelitian ini adalah siswa kelas VA SD Negeri Cebongan 02 Salatiga yang berjumlah 22 siswa, terdiri dari 10 siswa laki-laki dan 12 siswa perempuan. Penelitian ini menggunakan jenis Penelitian Tindakan Kelas (PTK). Menurut Bahri (2012:8) penelitian tindak kelas merupakan sebuah kegiatan yang dilaksanakan untuk mengamati kejadian dalam kelas untuk memperbaiki praktek dalam pembelajaran agar lebih berkualitas sehingga hasil belajarpun menjadi lebih baik. Dalam penelitian ini bentuk penelitian tindakan yang digunakan adalah peneliti bertindak sebagai guru, kemudian untuk mengatasi permasalahan yang terjadi dikelas VA yaitu dengan menerapkan model discovery learning dalam meningkatkan keaktifan dan hasil belajar siswa kelas VA SD Negeri Cebongan 02 Salatiga.

Penelitian tindakan kelas ini dilaksanakan dalam dua siklus yang tiap siklusnya terdiri dari empat tahap yaitu perencanaan, pelaksanaan, observasi, dan refleksi. Tahap pada siklus I yaitu: 1) Perencanaan, pada tahap ini kegiatan yang dilakukan ialah pembuatan RPP, menyiapkan alat peraga dan media, pembuatan lembar soal dan lembar observasi. 2) Pelaksanaan, pada tahap ini peneliti melaksanakan kegiatan pembelajaran sesuai dengan RPP yang telah disusun. 3) Observasi, tahap ini dilaksanakan selama kegiatan pembelajaran berlangsung. 4) Refleksi, pada tahap ini peneliti menganalisis keberhasilan dan kekurangan dari pembelajaran siklus I untuk memperbaiki pada tindakan berikutnya. Sedangkan tahap kegiatan yang dilakukan pada siklus II juga sama dengan siklus I, tetapi pada siklus II tindakan yang dilaksanakan merupakan perbaikan dari siklus I sehingga tindakan pada siklus II sudah terjadi penyempurnaan. Refleksi pada siklus ini akan merumuskan hasil dari semua kegiatan.

Adapun teknik dalam pengumpulan data yang digunakan yaitu tenik tes dan nontes. Tenik tes ini dilakukan dengan pemberian soal berbentuk pilihan ganda untuk mengukur kemampuan siswa setelah diberi perlakuan. Sedangkan nontes dalam penelitian ini berupa observasi menggunakan lembar observasi dengan rubrik penilaiannya untuk mendapat data tentang keaktifan siswa dan pengajaran guru di kelas. Kemudian data yang diperoleh dianalisis secara deskriptif.

\section{Hasil dan Pembahasan}

Sebelum dilaksanakan siklus I dan siklus II, peneliti terlebih dahulu melakukan observasi dan diskusi untuk mengetahui permasalahan yang ada di dalam kelas VA SD Negeri Cebongan 02 Salatiga pada pembelajaran tematik. Dengan dilakukan observasi dapat mengetahui kondisi awal kegiatan pembelajaran sebelum dilakukan tindakan dengan menggunakan model discovery learning. Dari hasil 
observasi ternyata proses pembelajaran belum memberikan pengalaman langsung kepada siswa sehingga siswa belum terlibat aktif dalam pembelajaran tematik yang menyebabkan siswa kurang sepenuhnya memahami materi sehingga berdampak pada hasil belajar siswa.

Berdasarkan hasil observasi yang dilakukan pada pra siklus diperoleh bahwa dari 22 siswa belum sepenuhnya terlibat aktif dalam proses belajar, hanya ada 5 siswa yang termasuk dalam kriteria aktif dengan presentase $22,73 \%$ dan 17 siswa lainnya masih tergolong pada kriteria sangat kurang aktif, kurang aktif dan cukup aktif dengan presentase $77,27 \%$. Kemudian hasil belajar siswa khususnya pada muatan IPA juga masih rendah, nilai rata-rata siswa adalah 66,6 dengan nilai tertinggi 80 dan nilai terendah 58, sedangkan siswa yang mencapai nilai KKM (72) hanya ada 6 siswa dengan presentase $27,27 \%$ dan siswa yang belum mencapai nilai KKM terdapat 16 siswa dengan presentase $72,73 \%$.

Kemudian dilakukan tindakan pada siklus I membahas materi pada tema 6 (Panas dan Perpindahannya) subtema 2 (Perpindahan Kalor di Sekitar Kita). Siklus 1 dilaksanakan pada 4-6 Maret, hari Senin 4 Maret 2019 untuk pertemuan pertama, Selasa 5 Maret 2019 untuk pertemuan kedua, dan pertemuan ketiga pada Rabu 6 Maret 2019 untuk memberikan soal evaluasi. Keaktifan belajar pada siklus I terdapat 12 siswa yang termasuk dalam kriteria aktif dengan presentase $54,55 \%$ dan 10 siswa lainnya masih dalam kriteria kurang aktif dan cukup aktif dengan presentase $45,45 \%$ sehingga dapat dilihat bahwa keaktifan siswa dari data awal sebelum diberi tindakan dan setelah diberi tindakan pada siklus I mengalami kenaikan sebesar 31,82\%, kemudian hasil belajar siswa juga mengalami peningkatan, diperoleh nilai rata-rata siswa adalah 75,09 dengan nilai tertinggi 89 dan nilai terendah 65, siswa yang mencapai nilai KKM ada 13 siswa dengan presentase 59,09\% dan siswa yang belum mencapai nilai KKM ada 9 siswa dengan presentase 40,91\%, dilihat dari ketuntasan belajar siswa dari data awal sebelum tindakan dan setelah tindakan siklus I mengalami kenaikan sebesar 31,82\%.

Dari hasil pelaksanaan pembelajaran pada siklus I ternyata belum mencapai target indikator keberhasilan penelitian, yaitu keaktifan siswa dapat dikatakan berhasil apabila $\geq 80 \%$ siswa mencapai dalam kategori aktif dan hasil belajar siswa dikatakan berhasil apabila $\geq 80 \%$ siswa mencapai ketuntasan. Sehingga penelitian dilanjutkan dengan melaksanakan siklus II. Setelah melaksanakan pembelajaran pada siklus I dengan menerapkan discovery learning, diperoleh beberapa catatan sebagai hasil observasi dalam pelaksanaan pembelajaran yang akan dijadikan sebagai refleksi untuk penyempurnaan pada pelaksanaan siklus II. Berdasarkan analisis hasil observasi diperoleh bahwa guru sudah melaksanakan pembelajaran secara runtut dan melibatkan siswa dalam penerapan model pembelajaran, beberapa juga siswa sudah mulai tampak terlibat aktif dalam pembelajaran. Akan tetapi, selama pelaksanaan pembelajaran pada siklus I ternyata masih terdapat beberapa kekurangan diantaranya: 1) Beberapa siswa masih bingung dengan kegiatan pembelajaran model discovery learning sehingga beberapa siswa belum bisa memahami materi secara leluasa. 2) Guru kurang menguasai kelas sehingga kelas terkadang masih ramai pada saat dibagi kelompok dan diskusi. 3) Beberapa siswa masih ada yang belum berani untuk bertanya dan berpendapat. 4) Masih terdapat siswa yang kurang bisa bekerja sama dengan baik, berdiskusi masih didominasi oleh siswa yang pandai saja dan masih ada siswa yang hanya diam saja bahkan ada yang bermain sendiri.

Untuk mengatasi kekurangan tersebut, maka dilakukan rencana perbaikan-perbaikan diantaranya: 1) Menjelaskan kembali kegiatan pembelajaran menggunakan model discovery learning kepada siswa secara lebih jelas atau rinci dan memberi pembimbingan lebih intensif. 2) Meningkatkan penguasaan kelas dan lebih tegas lagi dalam menghadapi siswa yang ramai dengan cara menegur dan memberi hukuman mengurangi nilai atau poin. 3) Memberi reward tambahan poin kepada siswa yang berani bertanya dan memberi tanggapan. 4) Memotivasi siswa untuk berani berpendapat ketika diskusi serta mengingatkan siswa untuk tidak bermain sendiri dan memberi pemahaman kepada siswa bahwa dalam berdiskusi dibutuhkan kerja sama kelompok yang baik serta tidak menggantungkan pada teman yang pandai saja. Selanjutnya hasil refleksi pelaksanaan pembelajaran pada siklus I dengan rencana perbaikannya tersebut akan dijadikan sebagai acuan pelaksanaan tindakan siklus II.

Tindakan pada siklus II membahas materi pada tema 6 (Panas dan Perpindahannya) subtema 3 (Pengaruh Kalor Terhadap Kehidupan). Siklus II dilaksanakan pada 11-13 Maret, hari Senin 11 Maret 2019 untuk pertemuan pertama, Selasa 12 Maret 2019 untuk pertemuan kedua, dan pertemuan ketiga pada Rabu 13 Maret 2019 untuk memberikan soal evaluasi. Keaktifan belajar pada siklus II terdapat 18 siswa yang termasuk dalam kriteria aktif dengan presentase $81,82 \%$ dan 4 siswa lainnya dalam kriteria cukup aktif dengan presentase $18,18 \%$. Peningkatan keaktifan siswa pada tiap siklus dapat dilihat pada diagram berikut. 


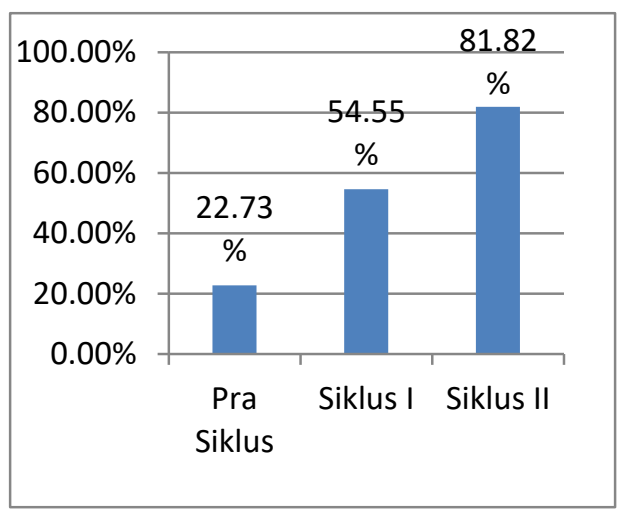

Gambar 1. Diagram Peningkatan Keaktifan Siswa

Berdasarkan diagram di atas dapat dilihat bahwa dari kondisi awal pada pra siklus ke siklus I siswa yang termasuk dalam kategori aktif mengalami kenaikan sebesar $31,82 \%$ sehingga pada siklus I menjadi 54,55\%, akan tetapi hal itu belum mencapai target indikator keberhasilan, kemudian siklus I ke siklus II siswa yang termasuk dalam kategori aktif mengalami kenaikan sebesar 27,27\% sehingga pada siklus II presentase keaktifan siswa menjadi 81,82\% dan hal tersebut sudah melebihi indikator keberhasilan yang ingin dicapai yaitu $80 \%$ siswa dikatakan aktif.

Sedangkan hasil belajar siswa juga mengalami peningkatan kembali, diperoleh nilai rata-rata siswa meningkat mejadi 80,36 dengan nilai tertinggi 91 dan nilai terendah 68, siswa yang mencapai nilai KKM bertambah menjadi 19 siswa dengan presentase 86,36\% dan siswa yang belum mencapai nilai KKM hanya ada 3 siswa dengan presentase 13,64\%. Peningkatan hasil belajar siswa pada setiap siklus dapat dilihat pada diagram berikut.

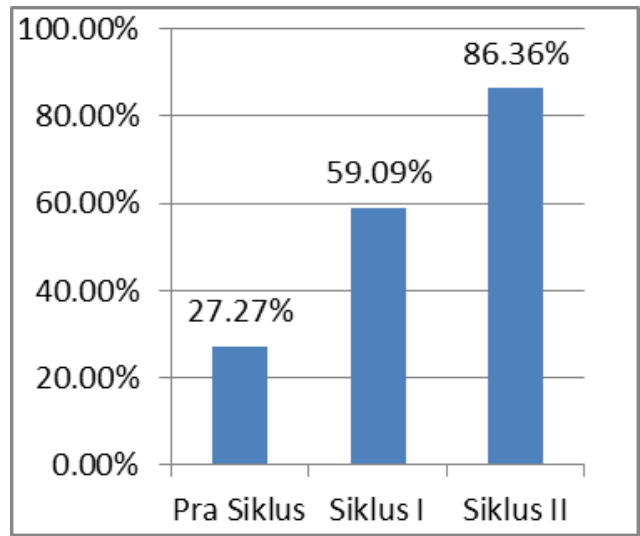

Gambar 2. Diagram Peningkatan Hasil Belajar Siswa

Berdasarkan diagram di atas dapat dilihat ketuntasan belajar siswa pada tiap siklus mengalami peningkatan. Dari pra siklus ke siklus I mengalami kenaikan sebesar 31,82\% kemudian siklus I ke siklus II mengalami kenaikan sebesar $27,27 \%$ sehingga pada siklus II presentase ketuntasan meningkat menjadi 86,36\%, sehingga hal itu menunjukkan hasil belajar yang diperoleh juga sudah melebihi indikator keberhasilan yang ditentukan yaitu hasil belajar siswa dikatakan berhasil meningkat apabila $80 \%$ siswa mengalami ketuntasan.

Berdasarkan hasil observasi selama pelaksanaan pembelajaran, guru sudah dapat menguasai kelas dengan baik, siswa telah sepenuhnya dapat melaksanakan kegiatan pembelajaran dengan discovery learning sehingga dapat memahami materi secara leluasa dan pembelajaran berjalan dengan baik, siswa sudah tidak terlalu ramai ketika berdiskusi, siswa juga sudah berani bertanya ataupun berpendapat dan siswa juga sudah dapat bekerja sama dalam kelompok dengan baik, meskipun masih ada siswa yang perlu diberi pembimbingan dan motivasi yang lebih lagi agar berani berpendapat. Akan tetapi secara keseluruhan hal tersebut menunjukkan bahwa kekurangan pada siklus I dapat teratasi sehingga pada siklus II kekurangan tersebut tidak terjadi lagi, dengan demikian proses pembelajaran menggunakan model discovery learning telah terlaksana dengan baik. 
Berdasarkan hasil penelitian di atas diketahui bahwa model discovery learning berhasil meningkatkan keaktifan dan hasil belajar siswa dari pra siklus sampai siklus II dikarenakan dalam menerapkannya sesuai dengan sintaknya dan guru berhasil memancing siswa untuk terlibat aktif dalam pembelajaran dengan menemukan dan mengorganisasikan konsep materi sendiri sehingga siswa dapat memahami materi pelajaran secara leluasa. Sesuai dengan pendapat Hanifah dan Wasitohadi (2017:95) bahwa discovery learning ialah rangkaian kegiatan pembelajaran yang melibatkan siswa untuk belajar aktif menemukan pengetahuan sendiri. Pendapat itu juga sejalan dengan pendapat Siswanti dan Wahyudi (2015:27) bahwa discovery learning merupakan proses pembelajaran di mana siswa tidak disajikan pelajaran dalam bentuk finalnya, tetapi diharapkan siswa mengorganisasi sendiri dan model ini lebih menekankan pada penemuan konsep atau prinsip yang sebelumnya tidak diketahui. Sehingga belajar dengan menggunakan model ini siswa akan penasaran dan lebih tertarik mengikuti pembelajaran sehingga dapat berpartisipasi aktif dalam kegiatan belajar dengan melakukan segala sesuatunya sendiri untuk dapat menemukan dan mengorganisasi materi sendiri dengan suatu percobaan atau pengamatan sehingga siswa akan lebih memahami materi secara leluasa.

Berdasarkan hasil analisis data, model discovery learning dapat meningkatkan keaktifan siswa dan hasil belajar siswa. Presentase keaktifan siswa awalnya hanya mencapai 22,73\% dengan hanya 5 siswa yang tergolong aktif, kemudian meningkat pada siklus I menjadi 54,55\% dengan 12 siswa yang tergolong aktif. Pada siklus II juga mengalami peningkatan menjadi 81,82\% dengan 18 siswa yang tergolong aktif dalam pembelajaran sehingga melebihi indikator keberhasilan yang ingin dicapai yaitu dengan presentase $\geq 80 \%$. Sedangkan presentase hasil belajar siswa awalnya hanya 27,27\%, kemudian meningkat pada siklus I menjadi 59,09\%. Pada siklus II juga mengalami peningkatan kembali menjadi 86,36\%. Hasil belajar yang diperoleh juga melebihi indikator keberhasilan yang ingin dicapai.

Dengan menerapkan model discovery learning pada pembelajaran tematik tema 6 (Panas dan Perpindahannya) di kelas VA SD Negeri Cebongan 02 Salatiga membuat kegiatan proses pembelajaran menjadi lebih menyenangkan dan lebih diminati siswa, hal ini terlihat dari antusiasme siswa dalam mengikuti kegiatan pembelajaran siswa berebutan untuk mempresentasikan hasil kerja kelompoknya dan menanggapi hasil dari kelompok lain. Siswa semakin aktif dalam bekerja kelompok untuk ikut serta menyelesaikan permasalahan yang diberikan oleh guru untuk menemukan konsep mengenai materi melalui kegiatan percobaan dan pengamatan. Siswa juga semakin tertarik dan termotivasi untuk bertanya maupun menjawab pertanyaan karena guru tidak menyampaikan materi seutuhnya sehingga membuat siswa menjadi penasaran kemudian tertarik untuk bertanya dan guru juga memberikan pancingan ataupun motivasi dengan memberikan reward kepada siswa yang berani bertanya ataupun menjawab pertanyaan. Sehingga hal itu dapat melatih siswa untuk dapat lebih percaya diri dan memiliki keberanian. Selain itu dengan menerapkan model discovery learning juga dapat menambah pengalaman belajar siswa, karena sumber belajar siswa untuk memperoleh informasi tidak hanya dari buku tema dan guru saja, tetapi siswa dapat memanfaatkan sumber belajar dari video, teman sekelas, kerja kelompok, dan juga dapat melalui kehidupan sehari-hari untuk memperoleh informasi. Dengan hal itu maka siswa dapat menguasai materi pembelajaran.

Hasil penelitian ini mendukung penelitian sebelumnya yang pernah dilakukan oleh Rita Y (2017), Istikomah, dkk (2018) dan Gina, dkk (2016) yang telah membuktikan meningkatnya keaktifan dan hasil belajar siswa dengan menerapkan model discovery learning. Hasil penelitian Rita Y (2017) diperoleh keaktifan siswa pada siklus I mencapai $50 \%$, siklus II $67 \%$ dan mengalami peningkatan pada siklus III 92\%. Sedangkan penelitian Istikomah N, dkk (2018) menghasilkan keaktifan siswa pada siklus I mencapai 86\% dan pada siklus II 95\%. Kemudian hasil belajar siswa dapat dilihat dari hasil penelitian Gina R, dkk (2016) yang menghasilkan, pada siklus I hasil belajar siswa mencapai presentase ketuntasan sebesar $26,92 \%$, siklus II mencapai presentase ketuntasan sebesar 65,38\%, pada siklus III mencapai 88,46\%.

Berdasarkan penelitian yang telah dilakukan oleh beberapa peneliti menunjukkan bahwa model discovery learning dapat meningkatkan keaktifan dan hasil belajar siswa. Namun pada penelitian ini terdapat kelebihan, diantaranya: 1) Pada penelitian ini menekankan dua aspek sekaligus yaitu keaktifan siswa dan hasil belajar siswa. 2) Menggunakan media yang ada di lingkungan sekitar siswa untuk percobaan maupun pengamatan dan permasalahan yang digunakan yaitu yang ada di sekitar kehidupan siswa sehingga penelitian ini dapat meningkatkan keaktifan dan juga hasil belajar siswa pada Tema 6 Panas dan Perpindahannya Subtema 2 Perpindahan Kalor di Sekitar Kita dan Subtema 3 Pengaruh Kalor Terhadap Kehidupan yang pada akhirnya dapat meningkatkan keaktifan dan hasil belajar siswa pada pembelajaran tematik kelas VA SD Negeri Cebongan 02 Salatiga semester II tahun pelajaran 2018/ 2019. 


\section{Simpulan Dan Saran}

Berdasarkan hasil analisis data dan pembahasan di atas, maka dapat disimpulkan bahwa dengan penerapan model pembelajaran discovery learning dapat meningkatkan keaktifan dan hasil belajar tematik siswa kelas VA SD Negeri Cebongan 02 Salatiga semester II tahun pelajaran 2018/ 2019. Hal ini dapat dilihat dari keaktifan dan hasil belajar siswa yang setiap siklus mengalami peningkatan. Pada kondisi awal atau pra siklus dari keseluruhan 22 siswa hanya terdapat 5 siswa yang termasuk kriteria aktif dengan presentase 22,73\%, kemudian siklus I mengalami kenaikan sebesar 31,82\% sehingga menjadi ada 12 siswa yang termasuk dalam kriteria aktif dengan presentase 54,55\%, kemudian pada siklus II mengalami peningkatan sebesar $27,27 \%$ sehingga menjadi ada 18 siswa yang termasuk dalam kriteria aktif dengan presentase $81,82 \%$. Selanjutnya hal yang sama juga terjadi pada hasil belajar siswa, pada pra siklus jumlah siswa yang tuntas hanya ada 6 dengan presentase $27,27 \%$, kemudian pada siklus I mengalami peningkatan sebesar 31,82\% sehingga yang tuntas menjadi ada 13 dengan presentase 59,09\% dan pada siklus II juga terjadi peningkatan kembali sebesar $27,27 \%$ sehingga jumlah siswa yang tuntas menjadi 19 dengan presentase $86,36 \%$.

Berdasarkan simpulan di atas, dapat disampaikan beberapa saran yaitu: 1. Bagi guru, dalam menerapkan model pembelajaran berbantuan media konkret pada proses pembelajaran dikelas perlu memahami langkah-langkah model pembelajaran inkuiri, serta memperhatikan: (a) Alokasi waktu diatur sebaik mungkin sehingga tiap tahapan pembelajaran dapat berlangsung secara optimal; (b) Pembagian kelompok harus benar-benar diperhatikan yakni secara heterogen berdasarkan jenis kelamin dan prestasi siswa; (c) Memberikan bimbingan individu dan kelompok secara merata; (d) Memahami sifat dan karakteristik anak, 2. Bagi siswa, siswa diharapkan berperan aktif dalam pembelajaran, memperhatikan penjelasan guru dan ikut terlibat dalam setiap kegiatan pembelajaran sehingga prestasi belajar akan meningkat serta diharapkan dapat berkerja secara mandiri maupun kelompok dan bertanggungjawab atas tugas yang diberikandan 3. Bagi Kepala Sekolah, diharapkan mengembangkan dan mengkaji lebih luas lagi model-model pembelajaran untuk mendukung proses belajar mengajar yang sesuai dengan kurikulum dan karakteristik anak meliputi sarana dan prasarana yang menunjang pembelajaran

\section{Daftar Rujukan}

Aini, Q., \& Relmasira, C. S. (2018). Penerapan model pembelajaran tematik integratif berbasis kontekstual untuk meningkatkan keaktifan dan hasil belajar siswa kelas 1 SD. Sekolah Dasar: Kajian Teori dan Praktik Pendidikan, 27 (2), 124-132.

Aningsih, \& Sapitri, I. (2018). Penerapan model pembelajaran inkuiri untuk meningkatkan keaktifan dan hasil belajar siswa pada pelajaran IPA materi benda dan sifatnya di kelas III. PEDAGOGIK, 6 (1), 50 58.

Bahri, A. (2012). Penelitian Tindakan Kelas. Makassar: Universitas Muhammadiyah Makassar.

Budimansyah, D. (2009). PAKEM Pembelajaran Aktif, Kreatif, Efektif dan Menyenangkan. Bandung: PT Genesindo.

Hanifah, U, \& Wasitohadi. (2017). Perbedaan efektivitas antara penerapan model pembelajaran discovery dan inquiry ditinjau dari hasil belajar IPA siswa. Jurnal Mitra Pendidikan, 1 (2), 92-104.

Hosnan. (2014). Pendekatan Saintifik dan Kontekstual dalam Pembelajaran Abad 21. Jakarta: Ghalia Indonesia.

Istikomah, N., Relmasira, C. S., \& Hardini, A. T. (2018). Penerapan model discovery learning pada pembelajaran IPS untuk meningkatkan keaktifan dan hasil belajar kognitif siswa sekolah dasar. Didaktika Dwija Indria, 6 (3), 130-138.

Kristin, F., Chintia, I. N., \& Anugraheni, I. (2018). Penerapan model discovery learning untuk meningkatkan kemampuan berfikir kreatif dan hasil belajar siswa. PERSPEKTIF Ilmu Pendidikan, 32 (1), 69-77. 
Kurniasih, I., \& Sani, B. (2014). Implementasikan Kurikulum 2013 Konsep dan Penerapan. Surabaya: Kata Pena.

Maharani, Y. B., \& Hardini, A. T. A. (2017). Penerapan model discovery learning berbantuan benda konkret untuk meningkatkan hasil belajar IPA. Jurnal Mitra Pendidikan, 1 (5), 249-561.

Putrayasa, M. I., Syahruddin, H., \& Margunayasa, G. I. (2014). Pengaruh model pembelajaran discovery learning dan minat belajar terhadap hasil belajar IPA. Jurnal Mimbar PGSD, 2 (1).

Rosarina, G., Sudin, A., \& Sujana, A. (2016). Penerapan model discovery learning untuk meningkatkan hasil belajar siswa pada materi perubahan wujud benda. Jurnal Pena Ilmiah, 1(1), 371-380.

Septiyani, T., Tampubolon, B, \& Rosnita. (2018). Peningkatan hasil belajar siswa menggunakan media konkrit pada pembelajaran tematik kelas I SD. Jurnal Pendidikan dan Pembelajaran, 7 (1), 1-10.

Siswanti, C. M., \& Wahyudi. (2015). Pengaruh pendekatan saintifik melalui model discovery learning dengan permainan terhdap hasil belajar matematika siswa kelas 5 SD. Scholaria: Jurnal Pendidikan dan Kebudayaan, 5 (3).

Widayanti, E. R., \& Slameto. (2016). Pengaruh penerapan metode teams games tournament berbantuan permainan dadu terhadap hasil belajar IPA. Scholaria: Jurnal Pendidikan dan Kebudayaan, 6 (3), 182-195. 